"The Curse of Race Prejudice": Debates about Racial "Prejudice" in the United States, c. 17501900

Nathan G. Alexander

Max Weber Centre for Advanced Cultural and Social Studies, University of Erfurt

nathan.g.alexander50@gmail.com

Word count: 6,740 words (excluding footnotes)

Disclosure Statement: I have no interests to disclose.

Author Bio: Nathan G. Alexander is a historian from Canada. He finished his $\mathrm{PhD}$ in Modern History at the University of St Andrews (UK) in 2016. He was most recently a fellow at the Max Weber Centre for Advanced Cultural and Social Studies at the University of Erfurt (Germany). 
"The Curse of Race Prejudice": Debates about Racial "Prejudice" in the United States, c. 17501900

Abstract: Debates about slavery, segregation, and racial inequality in the United States were often bound up with the meanings of racial "prejudice." In this article, I suggest that the concept was often double-edged: deployed both against racial inequality and oppression, but also to maintain it. Since the end of the eighteenth century, abolitionists and other advocates of racial equality charged that their opponents were possessed by irrational prejudice, which they sought to stamp out through a variety of means. In another line of argument, however, racial prejudice was natural or at least so deeply rooted from centuries of slavery as to be basically ineradicable. This meant that attempts to abolish slavery and establish an egalitarian, multiracial society were forever doomed to failure. Some people drew the lesson from this conception of prejudice that it might be best to remove blacks from American soil altogether by colonizing them elsewhere, particularly West Africa. Abolitionists, however, did not accept the idea that racial prejudice was invincible and thought it could be removed through greater education. After the Civil War, with the end of slavery, defenders of segregation drew on similar arguments, suggesting that if there were prejudices between the races, these resulted from the wisdom of the ages and should be respected, even as supporters of racial equality sought to show that these prejudices need not be permanent. This article therefore explores the complex and sometimes counterintuitive uses of the concept of racial "prejudice" from the late eighteenth century up until the subsequent development of the Jim Crow segregation regime in the late nineteenth century.

Keywords: racial prejudice; racism; slavery; segregation; United States; colonization; abolition; Civil War; conceptual history 
My title - taken from the white anarchist and atheist James F. Morton Jr.'s 1906 work, The

Curse of Race Prejudice - has a double meaning. ${ }^{1}$ In one sense, I mean it in the way that Morton meant it: "Race prejudice" was, to him and many others, a curse that harmed the nation and needed to be stamped out. ${ }^{2}$ Since the end of the eighteenth century, abolitionists and supporters of racial equality charged that their opponents were possessed by an irrational "prejudice" that made them discriminate against and oppress members of other races.

But the concept of "race prejudice" has also been a curse in American intellectual life in a different way. In this article, I suggest that the concept has also been deployed not against racial inequality, but actually to maintain it. In this line of argument, "race prejudice" was an ineradicable fact of life and to attempt to remove it was dangerous or, at best, futile. Distinct races naturally preferred their own kinds and would never be able to live harmoniously with other races. Even if some conceded that this prejudice was not natural, it was suggested that it was at least so deeply rooted from the centuries of slavery as to be essentially permanent. Used in this way, the concept could be deployed to argue against efforts to abolish slavery and establish a multi-racial society, since such measures would be doomed to failure. After the end of slavery, again, the permanence of prejudice was called upon to endorse segregation of the races.

This article will therefore explore the often double-edged nature of this concept of racial "prejudice" in the United States from the late eighteenth century up until the start of the twentieth. The article begins by discussing notions of "prejudice" in the eighteenth century, including its meanings in the Enlightenment, and early protests against slavery. It then discusses

\footnotetext{
${ }^{1}$ I would like to thank Colin Kidd and Don James McLaughlin for their comments on earlier drafts, as well as members of the Max Weber Centre for Advanced Cultural and Social Studies, University of Erfurt, who gave feedback on an early draft of this paper at the centre's colloquium. This article is part of a project that has received funding from the European Union's Horizon 2020 research and innovation programme under the Marie Skłodowska-Curie grant agreement No. 665958.

${ }^{2}$ James F. Morton Jr., The Curse of Race Prejudice (New York: Published by the author, 1906).
} 
reluctant opponents of slavery, who, while suggesting slavery was an evil, nonetheless could not imagine how it could ever be abolished given the influence of prejudice. The article then turns to the ostensibly benevolent movement to recolonize black people outside the United States and away from this ineradicable prejudice. Abolitionists however rejected these proposals and argued that it was indeed possible to vanquish prejudice. Finally, the article considers the use of prejudice in the decades after the Civil War, as segregationists argued the existence of prejudice made separation of the races necessary, while supporters of racial equality again attempted to show that prejudice need not be permanent.

\section{"Prejudice" in the Eighteenth Century}

The word "prejudice" has existed in English since the 1300s. The term has had two contradictory meanings for much of its history. The meaning most familiar to us today is "prejudice" as a premature judgment or a judgment formed in haste and without full examination. Another meaning, however, was of a previous judgment or a precedent. ${ }^{3}$ These two competing meanings can be seen in the Enlightenment of the seventeenth and eighteenth centuries. As Susan Rosa explains:

On the one hand, "prejudice" could denote any preconceived, inherited, or otherwise illthought-out opinion that inhibited the progress of knowledge. On the other, it could signify a time-honored and widely accepted or unquestioned assumption or practice that, as Edmund Burke put it in his Reflections on the Revolution in France (1790), had come, by virtue of its inherent "reasonableness," to constitute a "model ... and pattern ... of approved utility" in moral and political life. ${ }^{4}$

\footnotetext{
3 "prejudice, n.". OED Online. July 2018. Oxford University Press. http://www.oed.com/view/Entry/150162?rskey=iFluGF\&result=1\&isAdvanced=false (accessed November 29, 2018); see also Gordon W. Allport, The Nature of Prejudice, 4th Printing (Reading, MA: Addison-Wesley Publishing Company, 1966 [1954]), 6.

${ }^{4}$ Susan Rosa, "Prejudice," in Encyclopedia of the Enlightenment, ed. Alan Charles Kors (Oxford: Oxford University Press, 2005), http:/www.oxfordreference.com/view/10.1093/acref/9780195104301.001.0001/acref9780195104301-e-573.
} 
The former meaning of "prejudice" primarily concerned epistemology, while the latter primarily concerned practical ethical or political judgments. "Prejudices" in the first sense could be hindrances to the correct, rational understanding of the world, which Enlightenment thinkers sought to stamp out. But many seventeenth- and eighteenth-century thinkers also spoke of the necessity of "prejudices" - in the second sense - that were built up over the ages and ensured the moral and social order. To meddle with them therefore courted danger. From this standpoint, these customs - or "prejudices" - were not irrational at all, but were actually proved rational due to the fact that they "worked."

A similar dichotomy between "prejudice" as an error of reasoning versus "prejudice" as a custom or habit that had proved useful due its longevity would persist throughout the eighteenth and nineteenth centuries with regard to racial issues. There was of course ambiguity and overlap between the two meanings. Indeed, in some cases the issue was not about the phenomenon being described by the term, but rather whether a positive or negative evaluation was given to it. On the one hand were those abolitionists and supporters of racial equality who argued that prejudice obscured people's judgements, and if they could only conquer their prejudice, they would come to treat members of all races equally. On the other hand were those who suggested that prejudices between races, even if ostensibly regrettable, nonetheless had some utility given their long history, and it would be dangerous or at least futile to try to tinker with them.

The idea of prejudice applied to race did not seem to enter into anti-slavery arguments until the late eighteenth century. Winthrop Jordan, in his history of racial attitudes in colonial America, notes that "the concept of 'prejudice' toward social groups - the very term itself! -

\footnotetext{
${ }^{5}$ Ibid.; Michel Delon, "Prejudice," in Encyclopedia of the Enlightenment, ed. Michel Delon, vol. 2, 2 vols. (Chicago and London: Fitzroy Dearborn Publishers, 2001), 1086-88; see also J.M. Opal, "The Labors of Liberality: Christian Benevolence and National Prejudice in the American Founding," Journal of American History 94, no. 4 (2008): 1082-1107.
} 
came suddenly into wide currency in the years after 1760." Earlier anti-slavery works from the seventeenth and early eighteenth centuries did not seem to use this term. ${ }^{7}$ After this time, abolitionists began to add to their arguments the idea that there was a prejudice against those of African descent and that unprejudiced individuals should accept the equal capacity of all races. The famous abolitionist Anthony Benezet, for example, refuted arguments in favour of slavery that relied on the natural inferiority of black people in a 1762 work. There he supplied many accounts of the positive character of Africans in Africa and at the end of the work, he concluded that therefore "it must appear to every honest unprejudiced Reader, that the Negroes are equally intituled [sic] to the common Priviledges [sic] of Mankind with the Whites [...]." Samuel Hopkins, in his work A Dialogue Concerning the Slavery of the Africans (1776), asked why it was that whites would be outraged if their own racial group were being taken as slaves, yet seemed to care little when it was blacks taken as slaves. The reason, he thought, was clear: "our education has filled us with strong prejudices against them, and led us to consider them, not as our brethren [...]; but as quite another species of animals, made only to serve us and our children [...]." Hopkins hoped therefore that Americans could "divest ourselves of these strong prejudices $[\ldots] . " 9$

\footnotetext{
${ }^{6}$ Winthrop Jordan, White Over Black: American Attitudes Toward the Negro, 1550-1812 (Chapel Hill: University of North Carolina Press, 1968), 276.

${ }^{7}$ See, for example, George Keith, "An Exhortation and Caution to Friends Concerning Buying or Keeping of Negroes" (1693), in George H. Moore, ed., "The First Printed Protest Against Slavery in America," The Pennsylvania Magazine of History and Biography 13, no. 3 (October 1889): 265-70; John Hepburn, The American Defense of the Christian Golden Rule, or An Essay to Prove the Unlawfulness of Making Slaves of Men, 1715; Benjamin Lay, All Slave-Keepers That Keep the Innocent in Bondage, Apostates (Philadelphia: Printed for the Author, 1737).

${ }^{8}$ Anthony Benezet, A Short Account of That Part of Africa Inhabited by the Negroes (Philadelphia: W. Dunlop, 1762), 78.

${ }^{9}$ Samuel Hopkins, A Dialogue Concerning the Slavery of the Africans: Shewing It to Be the Duty and Interest of the American States to Emancipate All Their African Slaves (New York: Reprinted for Robert Hodges, 1785), 41.
} 


\section{Hesitant Opponents of Slavery and Prejudice}

There was, however, another way to conceive of "prejudice" in the late eighteenth century and into the nineteenth. Some thinkers seemed to agree that prejudice was unfortunate, but it was nonetheless probably ineradicable. This appears to be the case for the Founding Father Thomas Jefferson - himself a slaveholder, even if a highly conflicted one. ${ }^{10} \mathrm{He}$ thought slavery was unjust and harmful to both whites and blacks, but he could not see how slaves could be emancipated and then integrated into society with whites. In his Notes on the State of Virginia (1785-87), he wrote that "[d]eep rooted prejudices entertained by the whites; [and] ten thousand recollections, by the blacks, of the injuries they have sustained" were some of the reasons that these two races could never live together in harmony, in addition to the physical and moral differences that Jefferson saw between the two races. ${ }^{11}$ These ideas about the "deep rooted prejudices" of whites and the "recollections" of blacks of their past treatment would have a long influence in discourse about slavery, as we will see.

When Jefferson counselled his nephew Peter Carr to "shake off all the fears \& servile prejudices under which weak minds are servilely crouched," 12 he was referring to "prejudice" in general. Jefferson did not seem to give any credence to the idea that the particular racial prejudices could be removed in his Notes; these prejudices were an unhappy but probably unchangeable fact about the world. Jefferson likewise did not appear to count himself among the

\footnotetext{
${ }^{10}$ On Jefferson and slavery, see John Chester Miller, The Wolf by the Ears: Thomas Jefferson and Slavery (Charlottesville: University of Virginia Press, 1991); Paul Finkelman, "Thomas Jefferson and Antislavery: The Myth Goes On," The Virginia Magazine of History and Biography 102, no. 2 (April 1994): 193-228; Cassandra Pybus, "Thomas Jefferson and Slavery," in A Companion to Thomas Jefferson, ed. Francis D. Cogliano (Hoboken, New Jersey: Wiley-Blackwell, 2011), 271-83.

${ }^{11}$ Thomas Jefferson, Notes on the State of Virginia (1785-87) in Paul Leicester Ford, ed., The Works of Thomas Jefferson, vol. 4 (New York and London: G.P. Putnam's Sons, 1904), 49.

12 "From Thomas Jefferson to Peter Carr, with Enclosure, 10 August 1787," Founders Online, National Archives, version of January 18, 2019, https://founders.archives.gov/documents/Jefferson/01-12-02-0021. [Original source: The Papers of Thomas Jefferson, vol. 12, 7 August 1787-31 March 1788, ed. Julian P. Boyd. Princeton: Princeton University Press, 1955, pp. 14-19.]
} 
prejudiced. His own views on the physical and intellectual inferiority of blacks to whites were to him rational and scientific, even as he carried on some kind of relationship - the exact nature of which is unclear - with his slave Sally Hemings, with whom he had several children. ${ }^{13}$

Jefferson's ideas attracted criticism. Benjamin Banneker, a free black man, wrote to Jefferson in 1791, hoping to supply evidence against Jefferson's views of black inferiority by including a copy of his own almanac featuring detailed astronomical calculations. Banneker reflected on "the almost general prejudice and prepossession which is so prevailent [sic] in the world against those of my complexion." Banneker noted Jefferson's reported sympathies for the plight of blacks and therefore hoped to use his own achievements as an example to confront this prejudice. He did not want to recommend any particular actions, except "to wean yourselves from these narrow prejudices which you have imbibed with respect to them [blacks] [...]."14 Jefferson replied courteously and was enthusiastic enough to send a copy of the almanac across the Atlantic to the French philosopher Condorcet, however he would later express doubts that Banneker had authored the work without assistance. ${ }^{15}$

St. George Tucker, a lawyer and professor at the College of William and Mary, shared Jefferson's view of the enduring influence of prejudice as well as the injustice of slavery. Tucker proposed a complex plan for a gradual emancipation in Virginia, but he cited Jefferson's remarks from his Notes on the State of Virginia as one reason that incorporating the freed blacks into society as equals would be impossible. Tucker did not support banishing freed blacks from the

\footnotetext{
${ }^{13}$ See Annette Gordon-Reed, The Hemingses of Monticello: An American Family (New York and London: W. W. Norton \& Company, 2008).

14 “To Thomas Jefferson from Benjamin Banneker, 19 August 1791," Founders Online, National Archives, last modified June 13, 2018, http://founders.archives.gov/documents/Jefferson/01-22-02-0049. [Original source: The Papers of Thomas Jefferson, vol. 22, 6 August 1791-31 December 1791, ed. Charles T. Cullen. Princeton: Princeton University Press, 1986, pp. 49-54.]

${ }^{15}$ Finkelman, "Jefferson and Antislavery," 225; Manisha Sinha, The Slave 's Cause: A History of Abolition (New Haven and London: Yale University Press, 2016), 145.
} 
state, but he also did not want to see them placed on equality with whites. He asked, "if prejudices have taken such deep root in our minds, as to render it impossible to eradicate this opinion, ought not so general an error, if it be one, to be respected?"16 Here then, Tucker drew on the second sense of "prejudice" discussed above: the fact that these prejudices were so deeply embedded meant that one should proceed carefully before attempting to upend them.

Tucker's plan for gradual emancipation was very detailed and was paired with numerous restrictions on the civil rights of blacks. He recognized these restrictions might appear to be based in "prejudice," but

whoever proposes any plan for the abolition of slavery, will find that he must either encounter, or accommodate himself to prejudice. - I have preferred the latter; not that I pretend to be wholly exempt from it, but that I might avoid as many obstacles as possible to the completion of so desirable a work, as the abolition of slavery. ${ }^{17}$

Tucker pragmatically acknowledged that "prejudice" needed to be taken into account in making policy, even if he gave a vague indication that it was undesirable.

These ideas about the deep-rooted prejudices of whites as a fatal problem for emancipation would have a long influence throughout the nineteenth century among those who while not supportive of slavery - nonetheless had difficulty imagining emancipation. The tactic of using "prejudice" as an argument needed to be broached carefully. Explicit supporters of slavery could not make use of it, since doing so might suggest that their own views were clouded by irrational "prejudice." For those who said that they opposed slavery but could not conceive of emancipation, the idea of "prejudice" was useful. In this argument, "prejudice" was rarely something claimed for oneself, but it was possessed by other people. Emancipation was

\footnotetext{
${ }^{16}$ St. George Tucker, A Dissertation on Slavery: With a Proposal for the Gradual Abolition of It, in the State of Virginia (Philadelphia: Mathew Carey, 1796), 89.

${ }^{17}$ Ibid., 94.
} 
impossible because of the prejudices of others, not the one making the argument - who was

ostensibly more clear-headed. As Nicholas Guyatt perceptively writes:

In crafting national policies to address slavery or the future of Native Americans, liberal thinkers not only had to conquer their own prejudices, but also had to manage and account for those of poorer whites. In the process, they faced a terrible temptation: it would be easy to invoke the hostility of their less enlightened compatriots to mask their own reluctance to accept blacks and Indians as equals. ${ }^{18}$

Of course, such prophesies about the invincibility of prejudice were self-fulfilling (and selfserving), as many whites refused to meaningfully attempt to redress prejudice, while waving their hands about its invincibility and naturalness.

\section{Colonizationists and Prejudice}

These arguments about the durability of prejudices would also be used by the American

Colonization Society (ACS). ${ }^{19}$ This group, founded in 1816, aimed to transport free blacks, with their consent, ${ }^{20}$ primarily to the newly established colony of Liberia on the west coast of Africa. The ACS counted among its supporters many early nineteenth-century political luminaries, like the senator and statesman Henry Clay, as well as former presidents Thomas Jefferson, James Madison, and James Monroe (for whom the capital of Liberia, Monrovia, was named). The ACS

\footnotetext{
${ }^{18}$ Nicholas Guyatt, Bind Us Apart: How Enlightened Americans Invented Racial Segregation (Oxford: Oxford University Press, 2016), 28; see also George M. Fredrickson, The Black Image in the White Mind: The Debate on Afro-American Character and Destiny, 1817-1914 (New York: Harper \& Row, 1971), chapter 1.

${ }^{19}$ On the colonization movement, see P.J. Staudenraus, The African Colonization Movement, 1816-1865 (New York: Columbia University Press, 1961); Eric Burin, Slavery and the Peculiar Solution: A History of the American Colonization Society (Gainesville: University of Florida Press, 2005); Beverly Tomek, Colonization and Its Discontents: Emancipation, Emigration, and Antislavery in Antebellum Pennsylvania (New York: NYU Press, 2011); Ousmane K. Power-Greene, Against Wind and Tide: The African American Struggle against the Colonization Movement (New York and London: NYU Press, 2014); Beverly C. Tomek and Matthew J. Hetrick, eds., New Directions in the Study of African American Recolonization (Gainesville: University Press of Florida, 2017).

${ }^{20}$ Emigration to Liberia not necessarily always voluntary, since this could be a condition of manumission in slaveowners' wills. See Staudenraus, African Colonization Movement, 114.
} 
rejected charges that they supported slavery, but they did not see emancipation as a realistic possibility, for one thing because of the influence of racial prejudice.

Members of the ACS asserted that colonization provided a viable solution to the problem of a multiracial society by sending black people back to their ancestral homeland in Africa. At its most benevolent, the ACS argued that slaveholders would be more willing to free their slaves on the condition that they would be moved out of the country, and that therefore colonization was a practical solution to the problem of slavery - unlike the unworkable utopian schemes of the radical abolitionists. Nonetheless, their position on slavery itself was cautious and purposely non-committal, as they did not want to risk alienating potential allies, some of whom were slaveowners, by being too critical of the institution.

One of their frequent arguments for the impossibility of emancipation and the creation of a harmonious multiracial society was the enduring influence of deep-rooted "prejudice." 21 This can be seen in one of the earliest proposals for the creation of a colonization society, Robert Finley's pamphlet Thoughts on the Colonization of Free Blacks (1816). Finley suggested that blacks possessed the capacity for improvement and self-government, but this had no bearing unless they could be separated from the whites who used to rule them. Here he used very similar language to Jefferson's: “They will be kept down, on the one side by prejudice, too deep rooted to be eradicated, on the other, by the recollection of former inferiority, and despair of every assuming an equal standing in society."22

Similar arguments were made by a host of figures from the ACS. For example, in an 1819 letter, James Madison, who had long supported the idea of colonization, said that plans for emancipation should be "[c]onsistent with the existing and durable prejudices of the nation."

\footnotetext{
${ }^{21}$ Tomek, Colonization and Its Discontents, 50.

${ }^{22}$ Robert Finley, Thoughts on the Colonization of Free Blacks (Washington, 1816), 5.
} 
These "prejudices" were "probably unalterable" and therefore emancipation had to be coupled with the permanent removal of the free black population. To do otherwise would mean that blacks would constitute a dangerous element within American society, since they could never be equal and would therefore always resent the privileged class. ${ }^{23}$

A similar argument was made in an address to the Colonization Society of Kentucky by Henry Clay, a founding member of the ACS. Clay, himself a slaveholder, argued in an 1829 that free blacks were "the most corrupt, depraved, and abandoned" class. ${ }^{24}$ This was because of the harmful influence of prejudice: "Here invincible prejudices exclude them from the enjoyment of the Society of the whites, and deny them all the advantages of freemen. The bar, the pulpit, and our legislative halls are shut to them, by the irresistible force of public sentiment." ${ }^{25}$ Rather than trying to eliminate this "prejudice" or reform these laws, Clay reasoned that colonization was the only feasible option. In a later speech, this in 1839 , Clay warned of a violent struggle between the races in the event of the immediate abolition of slavery, fueled in part by the long-lasting influence of "prejudice" (again, in similar language to Jefferson's):

Embittered by all the recollections of the past, by the unconquerable prejudices which would prevail between the two races, and stimulated by all the hopes and fears of the future, it would be a contest in which the extermination of the blacks, or their ascendancy over the whites, would be the sole alternative. ${ }^{26}$

The language used by Clay in his speeches is telling. The "prejudice" was "invincible," "unconquerable," and "irresistible," meaning that emancipation could never be a realistic option

23 “Mr. Madison's Views on African Colonization," The African Repository and Colonial Journal, December 1861, 371 .

${ }^{24}$ Henry Clay, “An Address Delivered to the Colonization Society of Kentucky," The African Repository and Colonial Journal, March 1830, 12.

25 Ibid., 17.

26 "Speech of Mr. Clay, on the Subject of Abolition Petitions," The African Repository and Colonial Journal, February 1839, 61; for a similar argument, see Archibald Alexander, A History of Colonization on the Western Coast of Africa (Philadelphia: William S. Martien, 1846), 20. 
and that therefore the only viable solution was to separate the races as the colonizationists proposed.

It would be unfair, however, to view the colonizationists' arguments as entirely cynical. Prejudice really was a major stumbling block and it is not unreasonable to suggest that at least some colonizationists had genuinely benevolent motives in advancing these kinds of arguments. ${ }^{27}$ While the vast majority of free blacks strongly opposed colonization schemes, there were some who supported the ACS. One, quoted in the ACS's journal, argued that black people everywhere were able to show their virtues, “[y]et, alas! the prevalence of popular prejudice against our colour $[\ldots]$ has almost invariably stood as a barrier to our advancement in knowledge."28

But this view was in the minority; most free blacks actively fought against the ACS, fearing that the colonization movement would hinder their attempts for citizenship and inclusion within the nation, and would put them at risk for forced removals. ${ }^{29}$ Indeed, in the decades before the Civil War, only a few thousand blacks out of a population of about four million blacks, both free and enslaved, emigrated to Liberia. ${ }^{30}$ Historians have shown how the fierce protests of free blacks against the ACS in the 1820s fueled the growing abolitionist movement in the North. ${ }^{31}$

\footnotetext{
${ }^{27}$ As Eric Burin says of those slaveholders who manumitted slaves with the understanding they would go to Liberia: "The liberators sincerely believed that freedpersons would suffer under American racism." That said, Burin also adds that these slaveholders had practical motives for sending their slaves abroad and not to the North where they might join with abolitionists. Burin, Slavery and the Peculiar Solution, 44. See also Beverly Tomek's work, which argues that there was considerable overlap between the abolitionist and colonizationist movements. Tomek, Colonization and Its Discontents.

28 "Opinions of a Freeman of Colour in Charleston," The African Repository and Colonial Journal, October 1832, 240.

${ }^{29}$ Power-Greene, Against Wind and Tide.

${ }^{30}$ Patrick Rael, Black Identity and Black Protest in the Antebellum North (Chapel Hill and London: University of North Carolina Press, 2002), 275.

${ }^{31}$ On this point, see Paul Goodman, Of One Blood: Abolitionism and the Origins of Racial Equality (Berkeley and Los Angeles: University of California Press, 1998), chapters 3 and 4; Richard S. Newman, The Transformation of American Abolitionism: Fighting Slavery in the Early Republic (Chapel Hill and London: University of North Carolina Press, 2002), chapters 4 and 5; Sinha, The Slave's Cause, chapter 7.
} 
Both black and white abolitionists charged that the ACS actually created a hostile climate for black people by their insistence on the invincibility of prejudice.

For example, Lydia Maria Child, a white abolitionist, objected that, "instead of removing them away from the prejudice," it was better "to remove the prejudice away from them." 32 The objection of Charles Stuart, another white abolitionist, can be succinctly grasped from the title of his 1832 pamphlet: Prejudice Vincible. ${ }^{33}$ Prejudice was not, in other words, invincible, but could in fact be eliminated. Samuel Ennals, a free black man, in a speech given in New York in 1831, said: "There does exist in the United States a prejudice against us; but is it unconquerable? Is it not in the power of these gentlemen to subdue it? If their object is to benefit us, why not better our condition here?"34 An author in Freedom 's Journal, the first African-American owned newspaper, likewise wrote:

It is said by colonizationists, that such is the state of prejudice against our colour, and relative situation, that we never can be materially advanced in the scale of being, or possess any political advantages in this country; therefore it is necessary to colonize us, that we may be raised to our rightful standing. Is not this deifying prejudice, and paying homage at the shrine of one of the grossest sins, that ever disgraced the human family? ${ }^{35}$

Members of the ACS did not leave these charges unanswered. The British Quaker and abolitionist Thomas Hodgkin, who supported the ACS, took issue with the charge that colonizationists were unconcerned with "prejudice": "we hold it in as cordial abhorrence as our opponents can do; and we think we are taking measures for its removal, which promise to be more effectual than theirs." ${ }^{36}$ In other words, he did not necessarily disagree with the spirit of the

\footnotetext{
${ }^{32}$ Lydia Maria Child, An Appeal in Favor of That Class of Americans Called Africans (Boston: Allen and Tricknor, 1833), 146.

${ }^{33}$ Charles Stuart, Prejudice Vincible; or the Practicability of Conquering Prejudice by Better Means Than by Slavery and Exile, in Relation to the American Colonization Society (Liverpool: Egerton Smith and Co., 1832).

${ }^{34}$ Quoted in Ibid., 11.

${ }^{35}$ Investigator, “Colonization Society," Freedom's Journal, October 5, 1827, 2.

${ }^{36}$ Thomas Hodgkin, An Inquiry into the Merits of the American Colonization Society (London: J. \& A. Arch, Harvey \& Darton, Edmund Fry, and S. Highley, 1833), 16.
} 
abolitionists' goals, only whether they realistically stood a chance of success. Hodgkin thought colonization was actually the best solution to "prejudice." The ACS,

though it may appear in the first instance to yield to the prejudice which it cannot immediately destroy, is really preparing the death-blow for it, when it completely removes those who have been its victims from the sphere of its influence, to prepare them to re-appear in the field under new auspices. ${ }^{37}$

\section{Abolitionists and Prejudice}

The main goal of abolitionists was of course to end slavery, but they were also concerned with removing racial prejudice in order to achieve racial equality. While opponents of racial inequality argued that prejudices were natural, abolitionists suggested that prejudice was really an effect of slavery. Lydia Maria Child put it most succinctly when she said: "We made slavery, and slavery makes the prejudice." ${ }^{38}$ Given this, many hoped that with the disappearance of slavery, prejudice too would disappear. One author wrote: “[...] if you destroy slavery, prejudice and colonization will sink together into a dishonored grave." 39

While abolitionists agreed that prejudice was an outgrowth of the legacy of slavery, they were hopeful it could be removed in time. They rejected arguments that prejudice was natural or inherent and they cited cases where prejudice was absent, such as in Britain and Europe. One author wrote, for example, in The Colored American newspaper,

[i]n no country in Europe is any man excluded from refined society, or deprived of literary, religious, or political privileges on account of the tincture of his skin. If this prejudice is the fiat of the Almighty, most wonderful is it, that of all the kindreds of the earth, none have been found submissive to the heavenly impulse, excepting the white inhabitants of North America [...]. ${ }^{40}$

\footnotetext{
${ }^{37}$ Ibid., 29; for a similar defense of the ACS against charges of "prejudice," see "Professor Stowe on Colonization," The African Repository and Colonial Journal, November 1834, 300-304.

${ }^{38}$ Child, An Appeal, 141.

39 "Decline of Prejudice in Jamaica," The Liberator, August 17, 1838, 3.

40 "On the Condition of Free People of Color," The Colored American, March 7, 1840, 1; for another example, see N. Worcester, "The Prejudices of White People of Different Countries," The Liberator, March 31, 1837, 4.
} 
The absence of prejudice in Europe gave hope that it was not a permanent condition and could be removed. One abolitionist idea for removing prejudice was through introducing knowledge and facts to prejudiced people. In the first abolitionist newspaper, The Genius of Universal Emancipation, an article from 1823 said:

There can be little doubt that if the real character of the Africans and their descendants were sufficiently known among the people of the United States, $[\ldots]$ the force of prejudice would be weakened, and there would be much less difficulty in restoring to them the rights and privileges of which they have been unjustly deprived $\left[\ldots{ }^{4}{ }^{41}\right.$

An address from the Fifth Annual Convention for the Improvement of the Free People of Color likewise said, "[p]rejudice, like slavery, cannot stand the omnipotence of Truth." 42

Another way to reduce prejudice was for blacks to improve their own situation, which would in turn show the falsity of whites' prejudice. Somewhat patronizingly, white abolitionist authors wrote articles imploring blacks to improve themselves. One author wrote that for blacks, "something more than commonly good conduct is needed, in order to overcome the unfortunate prejudice against them." Whites' views, the author reasoned, were not wholly owing to irrational "prejudice," but also to the genuine lack of education among blacks. When blacks had made themselves equals to whites in knowledge and education, "they need not fear but what prejudice will die away, and their equality will be acknowledged and soon no difference will be known between the colored man and the white." ${ }^{43}$

\footnotetext{
41 "The Negro Character," The Genius of Universal Emancipation, October 1823, 55.

${ }^{42}$ Minutes of the Fifth Annual Convention, for the Improvement of the Free People of Color in the United States (Philadelphia: William P. Gibbons, 1835), 29.

${ }^{43}$ S.T.U., "What Can the Free Colored People Do For Themselves?," The Liberator, February 11, 1832, 1; for another example, see James Freeman Clarke, "Condition of the Free Colored People of the United States," The Liberator, March 25, 1859, 1.
} 
There was no doubt some naiveté to this position, but it was not unique to white people. As Patrick Rael shows, these arguments about the need for elevation and respectability as a tool to fight prejudice were also common among blacks. ${ }^{44}$ For example, an address from the Annual Convention for the Improvement of the Free People of Color, in 1832, read, "[i]f we ever expect to see the influence of prejudice decrease, and ourselves respected, it must be by the blessings of an enlightened education." 45 As Rael notes, one should not consider this strategy of uplift as meek submission to white standards, but an active use of black agency, even if hindsight did show the politics of "respectability" were mostly adopted in vein. ${ }^{46}$

Education of the young was another important tool to prevent the development of prejudice. Many authors contended that the absence of prejudice among children was proof that it was not natural and developed over the course of one's life. David Ruggles, a black abolitionist, asked, "[d]o children feel and exercise that prejudice towards colored persons? Do not colored and white children play together promiscuously until the white is taught to despise the colored?"47 To eliminate prejudice then would require paying attention to the upbringing of white children. The white abolitionist Gerrit Smith, for example, credited his own lack of "prejudice" to having children of different races as playmates while growing up. ${ }^{48}$ Another author wrote about the important influence of women to eradicate the "prejudices" of children under their care. ${ }^{49}$ For many abolitionists, Christianity was also a key to the removal of prejudice. A report of a speech by Reverend Andrew T. Foss, for example, noted that he said:

\footnotetext{
${ }^{44}$ See Rael, Black Identity, chapter 5.

${ }^{45}$ Minutes and Proceedings of the Second Annual Convention, for the Improvement of the Free People of Color in These United States (Philadelphia: Benj. Paschal, Thos. Butler, and Jas. C. Matthews, 1832), 34.

${ }^{46}$ Rael, Black Identity, 206.

${ }^{47}$ David Ruggles, The "Extinguisher" Extinguished! Or David M. Reese, M.D. “Used Up” (New York: D. Ruggles, 1834), 14.

48 "Letter from Gerrit Smith to Gov. Hunt, of New York, on African Colonization," The Liberator, March 5, 1852, 2.

49 "Prejudice," The Genius of Universal Emancipation, June 1830, 43.
} 
"This prejudice could be overcome by the education of a generation, and anti-slavery mothers should commence with their children, and take the New Testament as their guide." 50

Some abolitionists hinted at the limitations of the term "prejudice" and questioned whether a phrase like "prejudice against colour" was actually a misnomer. There was clearly more at work than simply a repulsion toward the colour black. An article in 1850 by Frederick Douglass likewise argued that it was not merely the skin colour that was the problem, but the social relations. If a black person was in a servile position, whites were happy to view them with amusement or friendliness, yet if that same person tried to improve their situation, they would be scorned. This indicated there was something deeper going on rather than merely a dislike of a person's race or colour. Ultimately,

[t]he evil lies deeper than prejudice against color. It is [...] an intense hatred of the colored man when he is distinguished for any ennobling qualities of head or heart. If the feeling which persecutes us were prejudice against color, the colored servant would be as obnoxious as the colored gentleman, for the color is the same in both cases; and being the same in both cases, it would produce the same result in both cases. ${ }^{51}$

Thus, for Douglass, the issue of "prejudice" was more complex than simply irrational thoughts in white people's minds, but had to do with the entire social structure of white domination.

\section{Supporters of Slavery and Prejudice}

The charge of "prejudice" was a powerful rhetorical tool wielded by abolitionists. For colonizationists, they tacitly agreed that prejudice was lamentable, yet could see no feasible way

\footnotetext{
50 "Business Meetings of the American Anti-Slavery Society," The Liberator, May 26, 1854, 1; for other examples, see "Speech of Gen. Howard," The Liberator, September 1, 1865, 1; "Christian Statesman," The Liberator, October $24,1851,1$.

${ }^{51}$ Frederick Douglass, "Prejudice Against Color," The North Star, June 13, 1850, 2; see also Hosea Easton, $A$ Treatise on the Intellectual Character, and Civil and Political Condition of the Colored People of the U. States; and the Prejudice Exercised Towards Them: With a Sermon on the Duty of the Church to Them (1837) in Hosea Easton, To Heal the Scourge of Prejudice: The Life and Writings of Hosea Easton, ed. George R. Price and James Brewer Stewart (Amherst: University of Massachusetts Press, 1999), 101-3.
} 
to get around it, meaning that the removal of blacks was the only option. For supporters of slavery, the issue of prejudice proved more difficult since to admit its existence might lead to suspicion that their own views were based in prejudice. Explicit defenses of slavery did not begin to be formulated in earnest until the abolitionist assault of the 1830s when many transitioned from earlier views of slavery as a necessary evil to slavery as a positive good. ${ }^{52}$

Detailed arguments against the charge of being prejudiced rarely featured in pro-slavery writings, although some admitted their prejudices while suggesting they were natural. Richard Colfax wrote, "it may be thought that we wish to keep alive old prejudices, which is partly true; for although we do not wish to create any rancorous hatred against the negroes, yet it is but proper that they should be viewed according to the intentions of nature [...]." 53 Indeed the inequality of free blacks in white society was "the result of a well founded prejudice [...]." 54 Here we see again the meaning of "prejudice" as an opinion that was proved correct through the fullness of time.

Another strategy was to reject the implication that defenders of slavery were making judgments without full knowledge. The South Carolina Senator William Harper argued in his Memoir on Slavery (1838) that white southerners were actually in the best position to judge the capacities of the black race, and therefore the charge of "prejudice" was not accurate: "We who have the best opportunity of judging, are pronounced to be incompetent to do so, and to be blinded by our interest and prejudices - often by those who have no opportunity at all [...]." The

\footnotetext{
${ }^{52}$ On the development of pro-slavery thought, see Drew Gilpin Faust, ed., The Ideology of Slavery: Proslavery Thought in the Antebellum South, 1830-1860 (Baton Rouge and London: Louisiana State University Press, 1981); Larry E. Tise, Proslavery: A History of the Defense of Slavery in America, 1701-1840 (Athens, Georgia: University of Georgia Press, 1987); Michael O'Brien, Conjectures of Order: Intellectual Life and the American South, 18101860 (Chapel Hill and London: University of North Carolina Press, 2004), chapter 18; Lacy K. Ford, Deliver Us From Evil: The Slavery Question in the Old South (Oxford and New York: Oxford University Press, 2009).

${ }^{53}$ Richard H. Colfax, Evidence Against the Views of the Abolitionists, Consisting of Physical and Moral Proofs, of the Natural Inferiority of the Negroes (New York: James T. Bleakley, 1833), 31.

${ }^{54}$ Ibid.
} 
"anatomist and physiologist" had made clear that the races differed anatomically, "yet there are some, who with a most bigoted and fanatical determination to free themselves from what they have prejudged to be prejudice," believed that blacks might yet be elevated to the ranks of whites. ${ }^{55}$ In this way, northern abolitionists were truly the ones blinded by "prejudice." ${ }^{56}$

As with the colonizationists, the existence of prejudices between races was a reason, to supporters of slavery, why emancipation was impossible. The idea that the two races could amalgamate into a single one following the end of slavery was delusional. As Harper said, "[w]hether it be accounted the result of prejudice or reason, it is certain that the two races will not be blended together so as to form a homogenous population." ${ }^{57}$ While Harper mooted the possibility that this seemingly natural repulsion was "prejudice," he ultimately thought this was an inaccurate characterization: "what if it be not prejudice, but truth, and nature, and right reason, and just moral feeling? As I have before said, throughout the whole of nature, like attracts like, and that which is unlike repels. ${ }^{" 58}$ In other words, there was good reason for whites to be opposed to amalgamation with blacks; it was not just irrational, and therefore intellectually suspect, "prejudice."

One author in the Southern Literary Messenger, seemed to suggest that prejudices between races were natural, even if, like Harper, he hedged about whether "prejudice" was really the right name. A flying squirrel and a mouse could not be put together happily in a cage for long, he observed; so it was with men of different races. While those of Spanish descent appeared to be able to live alongside blacks in the Americas, the races of northern Europe could

\footnotetext{
${ }^{55}$ William Harper, Memoir on Slavery (Charleston: James S. Burges, 1838), 37.

${ }^{56}$ For other criticisms of northerners as the truly "prejudiced" ones, see S.A. Cartwright, "How to Save the Republic, and the Position of the South in the Union," De Bow's Review 11, no. 2 (August 1851): 196; Albert Taylor Bledsoe, "Liberty and Slavery: Or, Slavery in the Light of Moral and Political Philosophy," in Cotton Is King and Pro-Slavery Arguments, ed. E.N. Elliott (August, Georgia: Pritchard, Abbott \& Loomis, 1860), 411-12.

${ }^{57}$ Harper, Memoir on Slavery, 55.

${ }^{58}$ Ibid., 57.
} 
not. Nonetheless: "I respect this prejudice as a matter of fact, without inquiring too curiously what part organic instinct plays, what part custom, and what part policy. We cannot be sure what ought to be, but only of what is."59

\section{The Post-Civil War Era}

In the aftermath of the Civil War and the end of slavery, debates about "prejudice" persisted. With the system of slavery now a dead-letter, southern whites attempted to construct a new system of racial control, and these thinkers echoed earlier notions of "prejudice" as something either natural or at least so deep-rooted as to be so. Authors sometimes disagreed that "prejudice" was the correct label for the phenomenon, but most agreed about its enduring presence.

By late in the nineteenth century, the authority of new disciplines of evolutionary and social science was increasingly called upon to endorse the naturalness of "prejudice." This case was made in, for example, Democracy and Race Friction (1914), by John Moffat Mecklin, a professor of philosophy at the University of Pittsburgh. There Mecklin approached segregation not as a symbol of crude racial prejudice, but as a necessary measure to preserve racial characteristics. Taboos surrounding mixed marriages were not merely irrational, he argued, but had their origins deep in the history of all species: "This instinctive aversion of one species for the other is nature's method of securing permanence of type even before the appearance of conscious choice as a factor." ${ }^{60}$ Mecklin continued, "Hence prejudice against colour may in its last analysis be prompted by laudable instincts of group self-preservation." ${ }^{61}$ Mecklin seemed to be saying that instances of prejudice were not really prejudice at all, but the manifestations of

\footnotetext{
59 “'Boston Notions.' A Letter and Reply,” Southern Literary Messenger 33, no. 4 (October 1861): 290.

${ }^{60}$ John Moffat Mecklin, Democracy and Race Friction: A Study in Social Ethics (New York: The Macmillan Company, 1914), 141.

${ }^{61}$ Ibid., 146.
} 
ancient psychological defenses of racial purity. They might be superficially irrational, but deep down there was a supreme logic to them. ${ }^{62}$

While these social scientific works were not explicit defenses of segregation regimes, others did use these kinds of arguments to advance the segregationist cause. In this view, racial "prejudice" was implanted into races either by natural selection or divine intervention in order to prevent racial intermixture. Laws against intermarriage, for example, were merely reflections of this "prejudice," and to attempt to pass laws ensuring social equality was dangerous and contrary to nature. For example, in 1887, the southerner H.S. Fulkerson cautioned that legislation attempting to enforce equality risked running up against the influence of prejudice. The Civil Rights Act of 1875, for example, was

a deliberate and senseless attempt $[\ldots]$ to legislate a prejudice of long standing out of existence. [...] There never did a prejudice exist in any mind without occasion of some kind for it, and the prejudices of a whole people are often as sacred to them as their persons or property, and they often go as far in defending them. ${ }^{63}$

In Thomas Dixon's historical novel celebrating the Ku Klux Klan, The Leopard's Spots (1902), one character makes a similar point: "What is called our race prejudice is simply God's first law of nature - the instinct of self-preservation." ${ }^{64}$ Edgar Gardner Murphy meanwhile wrote in 1904, "[t]he South has insisted, and has insisted wisely, on maintaining the absolute distinctness of racial life. The wisdom of this insistence, the deep sociological value of what has been called

\footnotetext{
${ }^{62}$ See also Nathaniel Southgate Shaler, "Race Prejudices," The Atlantic Monthly, October 1886, 510-18; Nathaniel Southgate Shaler, The Neighbor: The Natural History of Human Contacts (Boston and New York: Houghton, Mifflin and Company, 1904).

${ }^{63}$ H.S. Fulkerson, The Negro; As He Was; As He Is; As He Will Be (Vicksburg: Commercial Herald, 1887), 113.

${ }^{64}$ Thomas Dixon, The Leopard's Spots: A Romance of the White Man's Burden - 1865-1900 (New York: Doubleday, Page \& Co., 1902), 460.
} 
'race prejudice,' - despite its sometimes brutal and excuseless manifestations in every section, will have, I believe, an ever-widening recognition." 65

As with the pre-Civil War era, there continued to be those who critiqued the idea of "prejudice" as natural in the post-war period. In an 1881 article in the North American Review, Frederick Douglass took issue with the idea that the "prejudice" was "a natural, instinctive, and invincible attribute of the white race, and one that cannot be eradicated; that even evolution itself cannot carry us beyond or above it." 66 Douglass echoed earlier arguments that the seeming absence of prejudice in Britain and continental Europe, as well as the fact that there were many whites who had overcome their prejudice and that "prejudice" was really rooted in the historical experience of slavery not nature. ${ }^{67}$ Optimistically, Douglass wrote that, today, "the number of those who rise superior to prejudice is great and increasing." ${ }^{68}$ Other authors, opposing racial "prejudice," accepted the idea that "prejudice" was an instinctive feeling that could be located in humanity's evolutionary history, yet they were more optimistic that it could be removed through greater education and a changed social structure. ${ }^{69}$ For example, James F. Morton Jr., in his book, The Curse of Race Prejudice (1906), agreed with Douglass about the importance of slavery in forming prejudice, yet he also believed its roots could be found in early humanity's tribalism. But even if prejudice had a natural origin, history showed that it could stamped out. Morton viewed prejudice as similar to other errors of reasoning, like a belief in superstition or

\footnotetext{
${ }^{65}$ Edgar Gardner Murphy, Problems of the Present South: A Discussion of Certain of the Educational, Industrial and Political Issues in the Southern States (New York: The Macmillan Company, 1904), 63.

${ }^{66}$ Frederick Douglass, "The Color Line," North American Review 132 (June 1881): 569.

${ }^{67}$ Ibid., 571-73.

${ }^{68}$ Ibid., 577.

${ }^{69}$ Here, see William I. Thomas, "The Psychology of Race Prejudice," American Journal of Sociology 9 , no. 5 (March 1904): 593-611; George W. Ellis, “The Psychology of American Race Prejudice,” Journal of Race Development 5, no. 3 (January 1915): 297-315.
} 
witchcraft. To Morton, it was "not a foolish dream" to think we could get rid of "race prejudice," since these other "delusions" had too been rooted out in time..$^{70}$

Despite these critiques, the idea of "prejudice" as deeply rooted was itself a deeply rooted idea. Most clearly, court opinions on the constitutionality of segregation recognized the existence of prejudice yet eschewed intervention to try to remove it. It simply was not the job of the government to attempt to override natural prejudices, these courts suggested. An early case of this line of reasoning actually came from a northern state, Massachusetts, which had long prohibited slavery yet allowed segregated schools. The constitutionality of this was challenged in 1849, but the Massachusetts Supreme Court ruled that segregated schools were indeed constitutional. In the decision, the court referenced the idea of prejudice:

It is urged, that this maintenance of separate schools tends to deepen and perpetuate the odious distinction of caste, founded in a deep-rooted prejudice in public opinion. This prejudice, if it exists, is not created by law, and probably cannot be changed by law. Whether this distinction and prejudice, existing in the opinion and feelings of the community, would not be as effectually fostered by compelling colored and white children to associate together in the same schools, may well be doubted $[\ldots] .{ }^{71}$

Whether the court accepted arguments that segregated schools contributed to prejudice, they clearly did not see it as their job to attempt to rectify this prejudice by mandating interracial schools and, in any case, there was no guarantee interracial schools would achieve this aim.

As it happened, the Massachusetts legislature would, a few years later, pass a law prohibiting segregated schools, but the case was important in that its precedent would be cited by the infamous Plessy v. Ferguson Supreme Court decision in 1896, which ruled that "separate but equal" - the principle of the Jim Crow regime in the South - was constitutional. In other words,

\footnotetext{
${ }^{70}$ Morton Jr., Curse of Race Prejudice, 66; on Morton's racial views, see Nathan G. Alexander, Race in a Godless World: Atheism, Race, and Civilization, 1850-1914 (New York/Manchester: NYU Press/Manchester University Press, 2019), 188-94.

${ }^{71}$ Roberts v. Boston, 59 Mass. (5 Cush.) 198 (1850).
} 
states could pass legislation mandating segregated facilities, so long as equal provisions were granted for each race. The court's opinion on this case was written by Justice Henry Billings Brown, who disagreed with the plaintiff's arguments that segregation laws violated the fourteenth amendment which ensured equal protection before the law, regardless of race. Equal legal rights did not mean equal social rights, Brown insisted; "prejudice” would always work against the latter. The plaintiff's argument, Brown wrote, "assumes that social prejudices may be overcome by legislation, and that equal rights cannot be secured to the negro except by an enforced commingling of the two races. We cannot accept this proposition." Likewise, "[1] egislation is powerless to eradicate racial instincts or to abolish distinctions based upon physical differences, and the attempt to do so can only result in accentuating the difficulties of the present situation." 72 In a similar way to the court in Massachusetts, then, the Supreme Court considered prejudice to be so durable as to be beyond the powers of government to rectify. It was futile at best for the Court or the legislature to attempt to disrupt these deep-rooted prejudices.

\section{Final Thoughts}

Segregation persisted for about another half a century, when, in Brown v. Board of Education (1954), the Supreme Court threw out the "separate but equal" formula in relation to schooling and undermined the entire logic of Jim Crow. Indeed, the court drew upon the emerging social science research into the harmful ways segregated facilities promoted racial prejudice as reason to conclude that "[s]eparate educational facilities are inherently unequal." 73 This decision would pave the way for the end of legal segregation and the civil rights legislation passed in the 1960s.

\footnotetext{
72 Plessy v. Ferguson, 163 U.S. 537 (1896).

${ }^{73}$ Brown v. Board of Education of Topeka, 347 U.S. 483 (1954).
} 
Even still, white southerners resisted the push for integrated schools and some drew upon the idea of eternal prejudices. James Jackson Kilpatrick, for example, wrote in 1962:

The earliest history of man reflects an awareness of racial distinctions; in one fashion or another, discrimination has existed through all recorded time, and 'prejudice,' if you please, like the poor, has been with us always. ${ }^{74}$

Such a quotation gives an indication of the persistence of the view that prejudice was an unavoidable obstacle to racial equality. This article has shown the different and sometimes counterintuitive ways the concept of racial "prejudice" has been deployed in debates over slavery, segregation, and racial inequality. The most straightforward sense of this idea was to protest against those whites who seemingly held pre-conceived and wrongheaded views of black people. But the concept could also be deployed by those whites who wished to reinforce the racial status quo or to defend segregation, by appealing to unconquerable prejudices which existed between the races that made interracial harmony forever impossible. "Prejudice," therefore, was a "curse" in more ways than one.

In closing, I want to propose that there is yet another way in which the concept of "race prejudice" might be seen as a curse. The notion of "prejudice" suggests that the cause of racial inequality and discrimination was located in the minds of "prejudiced" individuals, whose thinking was defective. The fight against "race prejudice" was really therefore about correcting these mental errors through supplying new knowledge, which would in turn lead to racial equality. Over time, however, it would become clear that this was an insufficient strategy. The African American sociologist W.E.B. Du Bois, for example, reflected in an 1935 essay that black leaders used to think that "white Americans did not know of or realize the continuing plight of

\footnotetext{
${ }^{74}$ James Jackson Kilpatrick, The Southern Case for School Segregation (New York: Crowell-Collier Press, 1962),
} 183. 
the Negro." But, he continued, "[t]oday there can be no doubt that Americans know the facts; and yet they remain for the most part unmoved." 75 Already in the nineteenth century we saw thinkers like Frederick Douglass who were beginning to grasp that the issue of racial oppression was deeper than just individual mental states, but it would not be until the twentieth century when thinkers began to fully understand and articulate the structural or systemic reasons for racial inequality that went beyond the psychology of individuals.

${ }^{75}$ W.E.B. Du Bois, “A Negro Nation Within the Nation,” Current History 42, no. 3 (June 1, 1935): 266. 